\title{
Significance of lactate dehydrogenase in prediction of pregnancy induced hypertension and its complications
}

\author{
Kaur $\mathbf{R}^{1}$, Sonowal $\mathbf{R}^{2}$ \\ ${ }^{1}$ Dr Rupinder Kaur, Student, ${ }^{2}$ Dr Ramesh Sonowal, Associate Professor. Both authors are affiliated with Assam Medical \\ College and Hospital, Dibrugarh, Assam, India.
}

Address for Correspondence: Dr Rupinder Kaur, Email: rupinderkaur2132@gmail.com

\begin{abstract}
Objectives: To compare serum Lactate Dehydrogenase (LDH) level of normotensive pregnant women with those of preeclamptic and eclamptic women. To determine the relationship of levels of serum Lactate dehydrogenase with severity of pregnancy induced hypertension and its complications. Method: The study was carried out on pregnant hypertensive patients attending outpatient department of Obstetrics and Gynaecology department, AMCH Dibrugarh, Assam from $1^{\text {st }}$ July 2013 to $30^{\text {th }}$ June 2014. Normotensive pregnant women were taken as controls. Each serum sample from the control group as well as study group was estimated for Lactate Dehydrogenase using standard methods and a comparison was drawn and analyzed using t-test and chi-square test. Results: Serum Lactate Dehydrogenase level was high in the study group. The level of this enzyme was normal in the control group. Conclusion: Serum Lactate Dehydrogenase levels in patients suffering from preeclampsia and its complications are consistently higher as compared to the normotensive pregnant patients. The usefulness of this enzyme as marker of the severity of pregnancy induced hypertension and its universal inclusion along with other cardiac enzymes in the panel of investigations of pregnant women needs further large scale comparative studies.
\end{abstract}

Keywords: Maternal mortality, Lipid Metabolism, HELLP Syndrome.

\section{Introduction}

Pregnancy Induced Hypertension; a pregnancy specific condition still remains one of the major killers of the pregnant women [1]. A characteristic multi system disorder of pregnancy, pregnancy induced hypertension remains a therapeutic challenge for Obstetricians. It affects $7-10 \%$ of pregnancies world wide and in India the incidence is reported to be $8-10 \%$ of pregnancies $[2]$.

More than 4 million women across the world develop this disorder every year and an estimated 50000 to 76000 women die of this condition every year [3]. It accounts for approximately a quarter of all antenatal admissions and is the leading cause of maternal ICU admissions and causes 15 to $20 \%$ maternal deaths worldwide. The etiology of Pregnancy induced Hypertension still remains unknown. Once called

Manuscript received $14^{\text {th }}$ September 2016

Reviewed: $25^{\text {th }}$ September 2016

Author Corrected: $7^{\text {th }}$ October 2016

Accepted for Publication $18^{\text {th }}$ October 2016 'disease of theories' the etiological hypotheses presently forwarded are Placental ischemic hypothesis, Genetic hypothesis, Immune mal-adaptation hypothesis, Hypothesis of imbalance between scavengers and free radicals etc [4].

Oxidative stress seems to be the most acceptable of all these hypotheses in the present day Obstetrics.

Abnormalities of the lipid profiles and species may have a role in promotion of the oxidative stress and resultant vascular dysfunction seen in pregnancy induced hypertension.

There is increased evidence that the risk of Pregnancy induced hypertension is increased in women having abnormality of lipid metabolism but the causal relationship of abnormality of lipid metabolism with pregnancy induced hypertension is not yet definitely determined. 


\section{Materials and Methods}

The present clinico-biochemical study 'Significance of lactate dehydrogenase in prediction of Pregnancy induced hypertension and its Complications' was a prospective study carried out in the pregnant women attending the outpatient department of Obstetrics and Gynaecology of Assam Medical College, Dibrugarh. The study was carried out over a period of one year extending from $1^{\text {st }}$ of July 2013 to $30^{\text {th }}$ June 2014.

The study included 198 patients of which 100 were pregnant women with preeclampsia and eclampsia and the remaining were healthy normotensive pregnant women. Proper recommendation was obtained from the institutional ethical committee.

The women undertaken for study were divided into the following two groups:-

Group A (Control group):- 98 healthy normotensive pregnant women.

Group B (Study Group):- 100 pregnant women with Preeclampsia and Eclampsia. This was further subdivided into

1) Mild Preeclampsia :- $\mathrm{BP} \geq 140 / 90 \mathrm{~mm}$ of $\mathrm{Hg}$ with proteinuria.

2) Severe Preeclampsia :- $\mathrm{BP} \geq 160 / 110 \mathrm{~mm}$ of $\mathrm{Hg}$ with proteinuria

3) Eclampsia :- PIH with convulsion or coma.

The patients booked before 20 weeks who have crossed 20 weeks with singleton pregnancy with $\mathrm{BP} \geq 140 / 90 \mathrm{~mm}$ of $\mathrm{Hg}$ and proteinuria $\geq 300 \mathrm{mg} / 24 \mathrm{Hr}$ of urine or $\geq 1+$ Dipsticks were included in the study group. The patients hypertensive before 20 weeks of pregnancy and patients having acute urinary tract infection, chronic infections like cardiac, renal, liver, thyroid disease etc and with major obstetric complications like Antepartum Haemorrhage, twins, polyhydramnos were not included in the study.

\section{Method of Estimation of Serum Lactate Dehydrogenase (LDH)}

Modified I F C C method (IFCC: Enzymes 1994) [5]- This method devised by Wacker et al in 1980 and Vanderlinde 1982 is based on the reduction of pyruvate to lactate in the presence of N A D H by the action of lactate dehydrogenase. The rate of oxidation of $\mathrm{N} \mathrm{A} \mathrm{DH}$ to N A D is measured as a decrease in absorbance which is proportional to the L D H activity in the sample.

Pyruvate $+\mathrm{N}$ A D H $+\mathrm{H}$

Lactate + N A D

$\uparrow$

$\mathrm{LDH}$

Normal serum LDH level in pregnancy [4].

\begin{tabular}{|c|c|c|}
\hline Sl no & State & Level \\
\hline 1 & Non-pregnant & $115-221 \mathrm{IU} / \mathrm{L}$ \\
\hline 2 & First Trimester & $78-433 \mathrm{IU} / \mathrm{L}$ \\
\hline 3 & Second Trimester & $80-447 \mathrm{IU} / \mathrm{L}$ \\
\hline 4 & Third Trimester & $82-524 \mathrm{IU} / \mathrm{L}$ \\
\hline
\end{tabular}

Other relevant investigations done were:-

1) Blood -Hb\%, ABO Rh typing, VDRL, Blood Sugar, BT and CT, Urea, Creatinine, Uric Acid, Platelet Count, Thyroid function test and Liver Function test.

2) Urine- Sugar, Culture and Sensitivity.

3) $\mathrm{ECG}$ 


\section{Results and Observations}

The cases were divided according to the serum LDH and Serum AST levels in the following groups:- SERUM LDH

1) Serum $\mathrm{LDH}<600 \mathrm{U} / \mathrm{L}$

2) Serum LDH 600-800 U/L

3) Serum $\mathrm{LDH}>800 \mathrm{U} / \mathrm{L}$

Correlation coefficient was obtained by using Pearson correlation and significant values were obtained by using unpaired Student $t$ test, chi square test and Fisher exact test, wherever applicable.

Table-1: Distribution of Cases.

\begin{tabular}{|c|c|c|}
\hline Groups & No of cases & Percentage \\
\hline Group A & 98 & 49.49 \\
\hline Group B & 40 & 20.20 \\
Mild Preeclampsia & 30 & 15.15 \\
Severe Preeclampsia & 30 & 15.15 \\
Eclampsia & $\mathbf{1 9 8}$ & $\mathbf{1 0 0}$ \\
\hline Total & & \\
\hline
\end{tabular}

Table-2: Age wise distribution of the cases.

Maximum numbers of cases were between 20 to 25 years of age in both the groups. In group A $51 \%$ of the cases and in group B $47 \%$ of the cases were in this range. The number of patients in various groups is shown in the table 2.

\begin{tabular}{|c|c|c|c|c|}
\hline \multirow[t]{3}{*}{ Age(Years) } & \multicolumn{4}{|c|}{ Groups } \\
\hline & \multicolumn{2}{|c|}{$A(n=98)$} & \multicolumn{2}{|c|}{$B(n=100)$} \\
\hline & No & $\%$ & No & $\%$ \\
\hline $19-22$ & 22 & 22.46 & 28 & 28 \\
\hline $23-26$ & 48 & 48.97 & 46 & 46 \\
\hline $27-30$ & 17 & 17.35 & 14 & 14 \\
\hline $31-34$ & 10 & 10.20 & 9 & 9 \\
\hline $35 \&$ ABOVE & 1 & 1.02 & 3 & 3 \\
\hline
\end{tabular}

Table-3: Distribution of the cases according to parity in both the groups.

\begin{tabular}{|c|c|c|c|c|c|c|c|c|}
\hline \multirow[t]{3}{*}{ 'Parity } & \multirow{2}{*}{\multicolumn{2}{|c|}{$\begin{array}{c}\text { Group A } \\
(n=98)\end{array}$}} & \multicolumn{6}{|c|}{ Group B( $n=100)$} \\
\hline & & & \multicolumn{2}{|c|}{ Mild Preeclampsia } & \multicolumn{2}{|c|}{ Severe preeclampsia } & \multicolumn{2}{|c|}{ Eclampsia } \\
\hline & No & $\%$ & No & $\%$ & No & $\%$ & No & $\%$ \\
\hline Nulliparous & 56 & 57.14 & 22 & $55 \%$ & 25 & $83.34 \%$ & 23 & $76.6 \%$ \\
\hline Para -1 & 27 & 27.55 & 12 & $30 \%$ & 4 & 13.33 & 2 & $6.66 \%$ \\
\hline Para -2 & 11 & 11.22 & 6 & $15 \%$ & 1 & 3.33 & 1 & $3.33 \%$ \\
\hline Para-3 & 3 & 3.06 & 0 & & 0 & & 2 & $6.66 \%$ \\
\hline Para-4 & 1 & 1.03 & 0 & & 0 & & 2 & $6.66 \%$ \\
\hline Total & 98 & $100 \%$ & 40 & $100 \%$ & 30 & $100 \%$ & 30 & $100 \%$ \\
\hline
\end{tabular}

The above table makes it clear that out of 30 severe preeclampsia $83.34 \%$ cases were nulliparous, $13.33 \%$ were in para 1 and $3.33 \%$ in para 2 . In eclampsia out of 30 patients $76.6 \%$ were nulliparous and $6.66 \%$ were in majority of the other groups. 
Table-4: Gestational age at diagnosis of hypertension.

\begin{tabular}{|c|c|c|}
\hline \multirow{2}{*}{$\begin{array}{c}\text { Gestational Age } \\
(\text { In Weeks) }\end{array}$} & No & Group B ( n =100) \\
\cline { 2 - 3 } & 6 & 6 \\
\hline$\leq 28$ & 29 & 56 \\
\hline $29-32$ & 56 & 9 \\
\hline $33-37$ & 9 & $\mathbf{1 0 0 \%}$ \\
\hline$\geq 38$ & $\mathbf{1 0 0}$ & 56 \\
\hline
\end{tabular}

Maximum number of cases first detected as hypertensive were between 29 to 37 weeks. Hence maximum number of patients of preeclampsia and eclampsia were close to term pregnancy.

Table-5: Specific investigations:-Serum LDH Comparision of Serum LDH in both the groups.

\begin{tabular}{|c|c|c|c|}
\hline ENZYMES & $\begin{array}{c}\text { GROUP A(U/L) } \\
(\mathrm{MEAN} \pm \text { SD })\end{array}$ & $\begin{array}{c}\text { GROUP B } \\
(\mathrm{U} / \mathrm{L})(\mathrm{MEAN} \pm \mathrm{SD})\end{array}$ & $\mathrm{p}-$ Value \\
\hline Serum LDH & $198.0 \pm 30.03$ & $674.3 \pm 271.4$ & $<0.001$ \\
\hline
\end{tabular}

The mean values of serum LDH in the control group and in the study group were $198.0 \pm 30.03674 .3 \pm 271.4$ respectively and the mean value of serum AST in the control group and the study group were $26.42 \pm 5.82$ and $150.8 \pm 130$ respectively.

This was statistically significant proving higher serum values of LDH and AST in preeclampsia and eclampsia compared to normotensive pregnant patients.

Table-6: Serum LDH and systolic blood pressure association of systolic blood pressure with serum LDH in both the groups.

\begin{tabular}{|c|c|c|c|c|c|c|c|}
\hline \multirow{2}{*}{$\begin{array}{c}\text { Systolic BP } \\
(\mathbf{m m} \text { Hg) }\end{array}$} & \multicolumn{2}{|c|}{ LDH<600 U/L } & \multicolumn{2}{c|}{ LDH 600-800 U/L } & \multicolumn{2}{c|}{ LDH>800 U/L } & Total \\
\cline { 2 - 7 } & $\mathbf{N o}$ & $\mathbf{\%}$ & No & $\%$ & No & \% & \\
\hline $90-139$ & 98 & 70.50 & 0 & & 0 & & 40 \\
\hline $140-159$ & 37 & 26.62 & 2 & 12.5 & 1 & 2.33 & 60 \\
\hline$\geq 160$ & 4 & 2.88 & 14 & 87.5 & 42 & 97.67 & $\mathbf{1 0 0 \%}$ \\
\hline Total & $\mathbf{1 3 9}$ & $\mathbf{1 0 0 \%}$ & $\mathbf{1 6}$ & $\mathbf{1 0 0 \%}$ & $\mathbf{4 3}$ & $\mathbf{1 9 8}$ \\
\hline
\end{tabular}

Table-7: Serum LDH and diastolic blood pressure association of diastolic blood pressure with serum LDH in both the groups.

\begin{tabular}{|c|c|c|c|c|c|c|c|}
\hline \multirow{2}{*}{$\begin{array}{c}\text { Diastolic BP } \\
\text { (mm of Hg) }\end{array}$} & \multicolumn{2}{|c|}{ LDH<600U/L } & \multicolumn{2}{c|}{ LDH600-800U/L } & \multicolumn{2}{c|}{ LDH >800 } & $\begin{array}{c}\text { Total } \\
\text { Patients }\end{array}$ \\
\cline { 2 - 8 } & No & $\%$ & No & $\%$ & No & $\%$ \\
\hline $60-89$ & 94 & 67.62 & 0 & - & 0 & - & 94 \\
\hline $90-109$ & 42 & 30.22 & 5 & 31.3 & 10 & 23.3 & 57 \\
\hline$\geq 110$ & 3 & 2.16 & 11 & 68.7 & 33 & 76.7 & 47 \\
\hline TOTAL & 139 & $100 \%$ & 16 & $100 \%$ & 43 & $100 \%$ & 198 \\
\hline
\end{tabular}


Table-8: Association of serum LDH with complications of preeclampsia and eclampsia.

\begin{tabular}{|c|c|c|c|c|}
\hline Complications & LDH $<\mathbf{6 0 0 U / L}$ & $\begin{array}{c}\text { LDH 600-800 } \\
\mathbf{U} / \mathbf{L}\end{array}$ & LDH $>\mathbf{8 0 0}$ U/L & No of Patients \\
\hline Pulmonary edema & 0 & 0 & 20 & 20 \\
\hline Hypertensive retinopathy & 2 & 6 & 32 & 40 \\
\hline HELLP syndrome & 0 & 0 & 1 & 1 \\
\hline DIC & 0 & 0 & 5 & 6 \\
\hline Abruptio placentae & 0 & 1 & 9 & 9 \\
\hline Maternal death & 0 & 0 & 1 & 1 \\
\hline
\end{tabular}

The table clarifies that the complications of preeclampsia and eclampsia were more in the patients who had a high levels of $\mathrm{LDH}$.

\section{Discussion}

This study conducted over a period of one year included patients attending a referral hospital of Assam. The age of the patients ranged between 17 years to 36 years. Preeclampsia and severe preeclampsia were commoner in the primigravidae than multigravidae.

Preeclampsia is a complex pathophysiological condition where the regulatory system of inflammation and endothelial function is deranged unlike normal physiology of pregnancy. There is increased evidence that increased levels of lipids may play a pivotal role in modification of the endothelial function and structure.

Evidences are also emerging that deranged lipid metabolism in these cases are not a mere coincidence but are really involved in the pathogenesis of the disease and complications arising thereof. High levels of Lactate Dehydrogenase are implicated in these complications of pregnancy.

The patients in the study were mainly from the rural background and from lower middle class family. Majority of the patients in the study group developed hypertension in the third trimester of pregnancy which is comparable with the other studies like Walker J J et al, Redman CWG et al, Lardoux H et al etc $[6,7,8]$.

The mean values of serum LDH were normal $(198 \pm 30.03 \mathrm{U} / \mathrm{L})$ in the control group in comparison to the study group where levels were high (preeclampsia- $817 \pm 114 \mathrm{U} / \mathrm{L}$, eclampsia- $927 \pm 108 \mathrm{U} / \mathrm{L}$ ). The following table shows that these findings were comparable with various other studies.

Table-9: Comparison with other studies.

\begin{tabular}{|c|c|c|c|c|c|}
\hline \multirow[t]{2}{*}{$\begin{array}{l}\text { SL } \\
\text { NO }\end{array}$} & \multirow[t]{2}{*}{ Studies } & \multicolumn{4}{|c|}{$\begin{array}{c}\text { Serum LDH Levels (U/L) } \\
(\mathrm{MEAN} \pm \mathrm{SD})\end{array}$} \\
\hline & & Control & Preeclampsia & $\begin{array}{c}\text { Severe } \\
\text { Preeclampsia }\end{array}$ & Eclampsia \\
\hline 1 & Qublan et al 2002[8] & $299 \pm 79$ & $348 \pm 76$ & $774 \pm 69.6$ & $\begin{array}{ll}------ \\
\end{array}$ \\
\hline 2 & $\begin{array}{c}\text { R. Aziz \& T. Mahbooba } \\
\text { 2008[9] }\end{array}$ & $255 \pm 79$ & $343.34 \pm 59.17$ & ------- & ------- \\
\hline 3 & Jaiswar et al 2009[10] & $278 \pm 119.2$ & $400.45 \pm 148.21$ & $646.95 \pm 401.6$ & $1648 \pm 992$ \\
\hline 4 & Sonagra ad et al 2012[11] & $151.5 \pm 47.47$ & $356.46 \pm 158.09$ & $356.46 \pm 158.09$ & ------- \\
\hline 5 & Present study & $198 \pm 30.03$ & $372 \pm 76$ & $817 \pm 114$ & $927 \pm 108$ \\
\hline
\end{tabular}


So it is clear from the above that in cases of normotensive and preeclamptic patients the serum LDH levels remain below $600 \mathrm{U} / \mathrm{L}$ whereas in severe preeclampsia and eclampsia patients same remain above $600 \mathrm{U} / \mathrm{L}$.

Serum LDH levels were higher in patients with pregnancy induced hypertension. Likewise the complications of pregnancy induced hypertension like pulmonary oedema, abruption placentae, HELLP syndrome; DIC etc are higher in the patients with higher levels of serum LDH.

Preeclampsia [4]: It is a pregnancy specific syndrome with blood pressure measuring 140/90 $\mathrm{mmHg}$ or more and proteinuria $>300 \mathrm{mg} / 24 \mathrm{hrs}$, or persistent $30 \mathrm{mg}$ (1+dipstick) in a random urine samples after 20 weeks' of gestation. Severe preeclampsia is characterized by one of the following (ACOG, 2002a): Severe hypertension (BP $\geq 160 / 110$ $\mathrm{mmHg}$ ), proteinuria $>5 \mathrm{gms} / 24 \mathrm{hrs}$ or $3+$ or more on random samples, elevated serum creatinine levels, pulmonary edema, oliguria $<500 \mathrm{ml} / 24 \mathrm{hrs}$, microangiopathic hemolysis, platelet $<100,000 / \mathrm{cu} \mathrm{mm}$, elevated ALT and AST, epigastric pain, symptoms of end organ involvement and intrauterine growth restriction.

\section{Eclampsia [4]}

The onset of convulsions in a woman with preeclampsia that cannot be attributed to other causes is termed eclampsia. The seizures are generalized and may appear before, during, or after labor.

\section{Two stage model of preeclampsia}

- Stage 1 is preclinical and characterized by faulty trophoblastic vascular remodeling of uterine arteries that causes placental hypoxia.

- Stage 2 is caused by release of placental factors into the maternal circulation causing systemic inflammatory response and endothelial activation.

Instead of being simply "one disease," preeclampsia appears to be a culmination of factors that likely involve a number of maternal, placental, and fetal factors. Those currently considered important include:

1. Placental implantation with abnormal trophoblastic invasion of uterine vessels

2. Immunological maladaptive tolerance between maternal, paternal (placental), and fetal tissues

3. Maternal maladaptation to cardiovascular or inflammatory changes of normal pregnancy

4. Genetic factors including inherited predisposing genes as well as epigenetic influences.

\section{Summary and Conclusion}

In our study total number of patients was 198 of which 98 were normotensive pregnant patients included in the control group. The study population included mainly primigravidous subjects from lower and lower middle class families of 23 to 26 years of age.

Serum LDH levels were higher in patients with preeclampsia and eclampsia and in patients with complications of the pregnancy induced hypertension.

Raised levels of these enzymes are attributed to the cellular damage and multi organ dysfunction occurring during the course of the disease and increasing levels are seen as the disease progresses from mild to severe forms.
From our study, it can be concluded that serum levels of these enzymes correlate well with severity of hypertensive disorders of pregnancy and can be considered for inclusion in the panel of investigations for early management and to curb the complications of the disease.

\section{Funding: Nil, Conflict of interest: None. Permission of IRB: Yes}

\section{References}

1. Park K. Preventive medicine in obstetrics, pediatrics \& amp; geriatrics. In: Park K. (eds). Park's textbook of preventive and social medicine, 21st edn. M/s Banarasidas Bhanot publishers 2011, pp514-517. 
2. Chauhan R, Sharma RS, Parashar MK, Chauhan VS. Clinical examination of hypertension in pregnancy. In: Shah MR, editor. Hypertensive disorders in pregnancy: 1st ed. New Delhi: Jaypee Brothers Medical Publishers (P) Ltd; 2007. p. 111-25.

3. Trends in maternal mortality: 1990 to 2010 . WHO, UNICEF, UNFPA and The World Bankestimates. Availableat:http://whqlibdoc.who.int/publications/ 2012 / 9789241503631_eng.pdf. Accessed on July 12, 2012

4. Williams obstetrics, 23rd edition. Chapter 34. Pregnancy hypertension.

5. Bais R, Philcox M. Approved recommendation on IFCC methods for the measurement of catalytic concentration of enzymes. Part 8. IFCC Method for Lactate Dehydrogenase (l-Lactate: NAD+ Oxidoreductase, EC 1.1.1.27). International Federation of Clinical Chemistry (IFCC). Eur J Clin Chem Clin Biochem. 1994 Aug;32(8):639-55.

6. Redman CWG, Sargent IL, Roberts JM: Immunology of abnormal pregnancy and preeclampsia.In Lindheimer MD, Roberts JM, Cunningham FG (eds):Chesley \&\#39;s Hypertensive Disorders of Pregnancy, 3rd ed. New York, Elsevier, In press, 2009, p 129.
7. Redman CW, Sacks GP, Sargent IL. Preeclampsia: an excessive maternal inflammatory response to pregnancy. Am J Obstet Gynecol. 1999 Feb;180(2Pt 1): 499-506.

8. Qublan S. Hussain,Vera Ammarin. Osama Bataineh, Ziad Al-Shraideh, Yosef Tahat, Islam Awamleh, Basel Khreisat, Bassam Nussair,Zouhairodeh Amarin: Lactate dehydogenase as a biochemical marker of adverse pregnancy in severe preeeclampsia. Med.Sci. Monit 200511(8): CR 393-0397.

9. Rubina Aziz, Tabassum Mahboob: Relation between preeclampsia and cardiac enzymes, Arya Atherosclerosis Journal 2008, 4(1): 29-32.

10. Jaiswar S P, Gupta Amrit, Sachen Rekha, Natu SN, Shaili Mohan, Lactate Dehydrogenase: A Biochemical Marker for Preeclampsia -Eclampsia. The Journal of Obstetrics and Gynecology of India (NovemberDecember 2011) 61(6):645-648. DOI 10.1007/s 13224011-0093-9.

11. Amit D. Sonagra, Dattatreya. K. Jayaprakash Murthy D. SERUM LDH, ALP AND URIC ACID IN HYPERTENSIVE DISORDERS OF PREGNANCY IJPBS (VOL-2)Issue3/JULY-SEPT/2012/201-209.

\section{How to cite this article?}

Kaur R, Sonowal R. Significance of lactate dehydrogenase in prediction of pregnancy induced hypertension and its complications. Int J Med Res Rev 2016;4(11):1946-1952.doi:10.17511/ijmrr. 2016.i11.07. 